\title{
A Value Structured Approach to Conflicts in Environmental Management
}

\author{
Fred Wenstøp \\ BI Norwegian Business School \\ Norway
}

\section{Introduction}

The paper aims to suggest a way for OR practitioners to approach value conflicts in environmental management. The approach is claimed to be practical and at the same time theoretically well founded on three pillars: ethics, neuro-economics, and decision sciences.

The aim springs out of the concern that a rational approach to environmental management problems too often is hampered or even perverted by strong emotions elicited by value conflicts among stakeholders. Thus, considerable resources are frequently squandered on ill founded projects that may have detrimental effects. This could be mitigated if the OR analyst has a deeper understanding of ethical reasons for choice, as well as knowledge of practical methods to deal with values.

\section{OR relevance}

Environmental management problems involve facts as well as values. It is not only a question of being able to predict the outcomes of different actions, but we also need to decide whether the outcomes are good or bad. OR embraces an arsenal of tools to predict or optimize environmental consequences of human action. This includes System Dynamics, which highlights causal relations and dynamic effects; with The Limits to Growth (Meadows et al., 1972) as the most celebrated application. OR also embraces the field of Multi Criteria Decision Analysis (MCDA) which is designed to deal with values. Thus, OR appears to be well equipped to handle environmental problems. This is also evident from the number of papers being published in OR outlets on environmental issues. A simple count (May 2011) of papers with the word "environmental" in the title, abstract or among the key-words runs to 536 in Omega and 1608 in the European Journal of Operational Research. The tallies are respectively 96 and 42 for "sustainability".

While MCDA has methods to weight decision criteria, it has less to offer when ethical issues transcend the mere comparison of values (Wenstøp, 2005). This typically happens in environmental management cases where conflicts of rights and sense of duty often preclude discussion of consequences. This paper addresses that problem. 


\section{OR literature on value conflicts}

OR has not only a hard mathematical core, but also a rich tradition that emphasizes soft methods for structuring problems and to facilitate stakeholder involvement. Jonathan Rosenhead, with his Problem Structuring Methods, is one notable champion (Rosenhead, 2005). The current paper takes a more analytic approach than this, however. It has an emphasis on values and ethics, which can be traced as another OR tradition (Brans and Gallo, 2007), (Wenstøp, 2010), and within this tradition there are several publications on environmental management. One of the first contributors was Kenneth Boulding (1966) who coined the term "spaceship earth", signaling an early warning that energy, material, and environmental amenities are limited, and therefore require careful husbandry. More recently, Rauschmayer (2001) reflects on the normative foundation of MCDA and argue that decision criteria have to reflect not only the interests but possibly all values stemming from normative arguments of the decision-maker. This is especially true in environmental management where "the integration of values will result in changes of the MCA understanding, criteria building, and aggregation method, and will not be possible without analytical capacities of the decision analyst in ethics". Brans (2004) promotes Multi Criteria Decision Analysis as a suitable OR tool to take the interests of the stakeholders and Nature into account and calls for a multifaceted concept of ethics, consisting of Respect, Multi Criteria Management and Happiness. Kunsch (2009) discusses OR techniques to model decision-making problems with ethical dimensions, such as sustainability issues in the triangle of society, economy and environment, and Brans and Kunsch (2010) propose practical OR methods and tools for dealing with sustainability issues.

Le Menestrel and Van Wassenhove (2004), (2009) discuss the important issue of how to deal with the tension between the scientific legitimacy of OR models - where ethics is kept outside the models, and the integration of ethics within the models. The current paper is a voice in that debate. It takes Wenstøp and Koppang's (2009) view on OR and value conflicts as the point of departure and concludes that OR ought to handle decision problems involving value conflicts in environmental management by separating values according to ethical category.

\section{Outline}

When value conflicts arise in environmental management - which they often do - emotion laden arguments with an ethical undertone are notorious. I start the paper by elucidating this by narrating a dialogue regarding invasive aliens between a 'Socratic' journalist and a state employed environmental manager. I then propose to classify the arguments according to the classical ethical categories of virtue, duty and consequence. This makes it possible to set the conflict in a theoretical perspective by describing a consilience (Wilson, 1998) among the three ethical categories, three classes of values, and three kinds of emotions, and use that system to propose how the arguments can be organized and prepared for an OR approach to the problem. I finally recommend how OR ought to approach value laden decision problems in environmental management.

\section{Case: The alien raccoon dog}

The raccoon dog (Nyctereutes procyonides) is a small animal with short ears and a furry body. It enjoys high prestige in Japanese and Korean folklore where it is known as Tanuki, a merry 
and mischievous rascal, master of disguise, but a bit gullible. It looks somewhat like a racoon, but belongs to the same family as the dog. It was introduced to Russia from Korea around 1930 because of its fur, where after it migrated westward from Russia and reached Finnmark in northern Norway in 1983, where it has been observed six times during 2010. In Norway, the raccoon dog is officially considered alien, invasive and possibly detrimental to other species. It is considered a potential carrier of tapeworm and rabies. The Directorate for Nature Management (DNM) - one of five governmental agencies under the Ministry of Environment - developed an action plan (2008) to prevent its invasion of Norway. It has the form of a 17 page document with a front picture of an aggressive raccoon dog attacking a Norwegian magpie. It is presented as opportunistic, alien and harmful, a carrier of tapeworm and rabies, an alien species that must be exterminated.

The following is a narrative of an interview published in a Norwegian newspaper (Q) with an advisor in DNM (A) (Sætre, 2010). Since one important reason for exterminating the raccoon dog is that it may carry tapeworm this was a natural start of the dialogue:

Q: Dogs and foxes carry tapeworm as well? A: Right, but raccoon dogs wander more.

Q: Wolves carry rabies too? A: Yes, but raccoon dogs may spread rabies faster.

Q: The potato is also alien? A: All cultural plants are alien. We wanted them for food. Our civilization depends on this. But we think differently now...

Q: How many raccoon dogs are there in Norway? A: Two, for certain, but there may be more. And if we allow them to breed, they will soon threaten our Norwegian animals, who have lived in peace and harmony. Sitting ducks are especially vulnerable.

Q: Why is it more important for us to have ducks than raccoon dogs? A: Hunting; it is a traditional pastime to hunt ducks. So this is a value based choice.

Q: So what you mean is that our values decide for ducks and against raccoon dogs? A: Yes, and that is quite legitimate. Hunting traditions you know. The experience of having ducks around...

Q: So we might turn this around then and argue that the raccoon dog is valuable? A: Yes, you are free to do that, but the Norwegian policy is to prevent it from establishing itself. If it does, we may not even pick blueberries any more because of tapeworms. The raccoon dog is Asian and belongs there, not here. Similarly with the mink; it was introduced in 1930, but now we shall kill it. The black headed gull, on the other hand, has flown here on its own wings, therefore it may stay.

Q: How long must you have been here, before you are accepted? A: The mink is alien, and will never be accepted.

Q: But the raccoon dog has walked on its own legs from Russia? A: Yes, but it was transported from Korea to Russia. Had it walked all the way by itself, it would have been different.

Q: Why are we spending large amounts of money on reintroducing the wolf - which eats us - while we shall exterminate the raccoon dog which just plays dead when threatened? A: This is a political decision.

Q: Do you hate raccoon dogs? A: This is not about emotions, but about scientific judgment.

Q: But still, why will you reintroduce wolves but exterminate the raccoon dog? A: It is a question of value based choice..

Q: What kind of values? A: What we want with Norwegian nature...

This case was chosen because it reveals typical human concerns as they shift between rights and consequences. We can be emotionally swayed by questions of aliens' rights, as well as 
by a sense of duty to preserve or restore the environment to some pristine state. That such attitudes are common can be documented by the reactions to the article, "Don't judge species on their origins" (Davis et al., 2011). The authors clearly hit a nerve with an amazing 10400 hits on a Google search (24.08.2011) with the full title. Most comments seem to be supportive of the article, but there are also a number that are negative, such as Hough Snee of Perceptible Changes (2011). Davis et al. observe that "'non-native' species have been vilified for driving beloved 'native' species to extinction and generally polluting 'natural' environments. Intentionally or not, such characterizations have helped to create a pervasive bias against alien species that has been embraced by the public, conservationists, land managers and policy-makers, as well as by many scientists, throughout the world." Their main point is that management of introduced species should be based on rational, not emotive reasons. Vince (2011) has a similar opinion based on experience from the Galápagos, where eradication programs of invasive plants like blackberries have proven futile. But on the other hand, the resulting hybrid ecosystem turned actually out to be acceptable and could even be "worthy of conservation". That a species is alien is actually a poor predictor of its environmental impacts, which can be detrimental as well as beneficial.

The issue of being native or alien was first introduced by the English botanist John Henslow in 1835. However, it was not until the 1990's that it became a global public policy to try and preserve pristine environments by eradicating aliens (Wittenberg and Cock, 2001) since they were considered to be a leading threat to biodiversity and a cost to human enterprises, as well as a threat to health.

\section{Ethical theories}

The three classical ethical mindsets of consequentialism, duty ethics, and virtue ethics give different reasons for choice (Blackburn, 1998). According to consequentialism, an action is morally good if the intended consequences are good. Consequentialism thus makes the good prior to the right, and it defines the right operation in terms of promoting the good. Thus, a consequentialist looks neither at the nature of the action itself, nor at the character or attitude of the decision-maker: only consequences count. This contrasts with Kantian duty ethics that defines the right prior to the good. The principle of morality according to Immanuel Kant is to act only on that maxim through which you at the same time will that should become a universal law. It considers whether the decision-maker has obeyed the right principles, and thereby fulfilled her duty or obligations, no matter what the consequences are. Finally, virtue ethics is only concerned with the character and attitude of the decision-maker; an action is morally right if the relevant virtues have been displayed, such as courage, loyalty etc. To be principled is a virtue as well, and this provides a link between duty and virtue ethics: to fail at duty ethics is to fail at virtue ethics (Wenstøp and Koppang, 2009). The reason I call the three ethical theories 'mindsets' is that people are often unaware of their own reasons for choice, even though an ethical mindset pervades their emotions and thinking. Making people aware of this would provide for better mutual understanding in value conflicts (Wenstøp, 2005).

\section{Classification of arguments}

The dialogue in the case has the appearance of a bewildering - sometimes contradictory array of arguments and attitudes, which may become clearer if one could classify them 
according to reasons for choice. Thus, the three classical ethical theories of virtues, duties and consequences are natural candidates.

One class of arguments in the case describes the character of the alien; the raccoon dog is portrayed as evil. While this is sometimes said to vilify human immigrants, it is questionable when used against animals. Is a cat playing with a mouse evil, or just inquisitive? Still, it is natural to classify such arguments under the label "virtue ethics" since virtue has to do with the character of the agent, in this case the raccoon dog. And accusations of want of virtue are bound to elicit strong negative emotions such as disgust, anger or xenophobia.

The next class of arguments is about rights. Who has the right to live in Norway? The argument goes that you are okay if you have arrived by walking, but you must walk (or fly) the whole way; half is not enough. As rights have to do with laws and rules, I propose to classify these arguments under duty ethics. The question of right to land is of course problematic, be it human immigrants, plants or animals. But regardless of who the transgressor is, violation of perceived rights generally elicits very strong negative emotions. Baron and Spranca (1997) have introduced the term 'protected values' for values that are protected by rules or rights. The dialogue also has an undertone of a sense of duty to preserve or restore a pristine environment; an attitude which is prevalent among lay people and conversationalists alike.

The third class of arguments has to do with what we want with Norwegian nature. In other words: what would be the consequences if we welcomed the raccoon dog, and do we like those consequences? Such issues belong to consequentialism; the value of an action depends solely on its consequences. This is the third ethical category and it is interesting to note that the answer requires for and against judgments, where the raccoon dog's character weighs in on the scales.

Consequentialism appears to be the most common attitude among environmental scientists, while duty ethics often underpin the attitudes of managers and policy-makers. But sometimes there is a hierarchy of ethical platforms: According to the authoritative "Toolkit of Best Prevention and Management Practices" for control of "Invasive Alien Species" (Wittenberg and Cock, 2001), "the ultimate goal of the strategy should be preservation or restoration of healthy ecosystems". Thus there is a duty to preserve or restore, but then one has to define what healthy means. This brings us into the realm of consequentialism where one needs to identify criteria for healthiness: "Thus, the initial step in a national programme must be to distinguish the harmful from the harmless alien species and identify the impacts of the former on native biodiversity." (Ibid.)

\section{Affect and deliberation}

We have already identified emotions as a factor at work in environmental discussions. To understand the deeper connection between ethics and emotions, it is useful to consider the emerging field of neuroeconomics, which studies neural correlates of economic decisionmaking (Camerer et al., 2005). Neuroscientists use several techniques, such as positron emission topography (PET) scanning and functional magnetic resonance imaging (fMRI), to monitor the location and pattern of neural activity in the brain when decisions are made. They have established that there are two kinds of neural processes involved in decisionmaking: cognitive and affective. This comes as no surprise; Plato characterized human 
behavior as riding in a chariot drawn by two horses, reason and passion. What is new is that we can now observe that humans actually are hard-wired in that way, and that the processes often compete for dominance. Passion is quick in the onset, sometimes evoking immediate action before the slower deliberate processes can become engaged and hinder an unreasonable response.

It is interesting to note the fields of law and economics have different traditions in this respect. The concept of homo economicus or 'economic man' is strong in economics. Here, passions are kept at arm's length, and it is assumed that self-interested actors have the ability to make deliberate judgments toward their subjectively defined ends. Law, however, incorporates a notion of passion exemplified by the legal maxim Ira furor brevis est (anger is short insanity) and this is occasionally used to excuse an offender.

\subsection{Emotions}

Neuroscientists have demonstrated that affective states have somatic correlates, i.e. emotions that work together or in competition with reasoning processes to shape decision making. Thus, neuroeconomics seeks to bring passion back into economic models to build more complete models of human decision processes. Emotions need not be consciously felt, but almost all actions seem to be prompted by emotions. They work to improve our affective state by giving the body appropriate response signals. The interplay between affective processes in our brain and emotions in our body is massively parallel, with many pathways working simultaneously and rapidly, supporting the observation that we sometimes act before we have time to think.

\subsection{Conation}

According to ancient wisdom, Conatus is one of three parts of the mind, along with the affective and cognitive. While feelings come from the affective system and thoughts from the cognitive system, the conative system drives how one acts on those thoughts and feelings. These classical concepts where known to Aristotle and are congruent with another important observation in neuroscience: that cognitive processes alone cannot produce action. Conation - the desire to act - requires that the cognitive system works through the affective system. Any action is preceded by an emotion. The picture is therefore that although the cognitive system is used for searching for options and predicting consequences of actions, it cannot evaluate those consequences. That must be done by the affective system. Damasio (1994) made notable empirical observations in neuroscience when he discovered that people with damage to the prefrontal lobes were emotionally flat when they contemplated future consequences of decisions. As a consequence, they were very poor decision-makers, sometimes being completely unable to make decision, sometimes making decisions that were obviously detrimental to their own well-being. These people had severed the connection between the cognitive system and amygdala, which is responsible for eliciting somatic responses. According to Damasio, it is the feeling of these emotions that prompt action. In the words of Camerer et al. (2005) "It is not enough to "know" what should be done; it is also necessary to "feel" it". Figure 1 shows a model of the two processes of affect and deliberation involved in conation. 


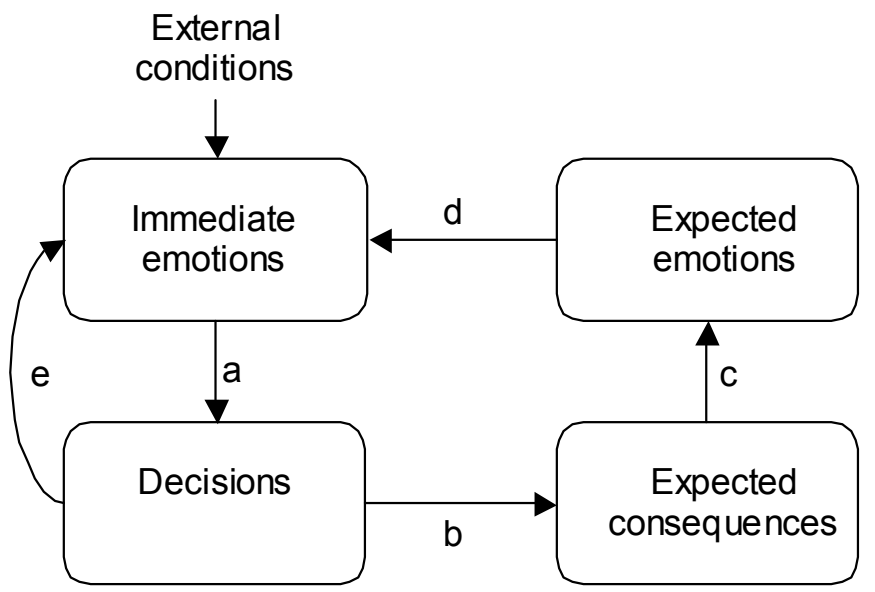

Fig. 1. A model of decision-making between affect and deliberation, adapted from Loewenstein and Lerner (2002). Path a: all decisions are prompted by immediate emotions. The cognitive pathway a-b-c-d is employed in deliberation, which involves prediction of consequences of alternative decisions and how good they will feel. The expected emotions influence immediate emotions, which in turn may prompt action. Pathway e is the affective pathway caused, for example, by fear or disgust that may affect immediate emotions more strongly than expected emotions.

Figure 1 illustrates the two - often competing - processes involved in conation: The affective pathway a-e-a, and the deliberate pathway a-b-c-d-a. Both pathways involve emotions, the difference being that they are fast and strong in the affective pathway and slow and temperate in the deliberate one. The affective pathway, however, does not involve cognitive processes; here one acts without thinking.

With this background, it is easier to understand the mechanisms behind conflicts in environmental management. Conflicts are created by the opposing forces of strong affect in some stakeholders and tempered emotions in another stakeholder. For example, pathway e represents one stakeholder's affect resulting from the perceived virtues of animals - be they bad (raccoon dogs) or good (whales). Another stakeholder may have a more balanced emotional response elicited through rational deliberation about consequences of actions, using the pathway a-b-c-d. Such conflicts can even be intra-personal - as when a person is of different minds - not only interpersonal, as when stakeholders argue from the vantage points of divergent mindsets.

\subsection{Rationality}

If we want to define rationality in a way that makes rationality bode well for decisionmaking, it is important to note that the cognitive pathway in Figure 1 involves emotion, suggesting that a good definition of rationality should incorporate it. Since pure thinking is not sufficient to prompt action, any concept of rationality that does not incorporate emotion would be insufficient. Rationality requires that deliberation about consequences be infused 
with emotion (pathway b-c-d), while one avoids strong affect (pathway e) that precludes thinking. Therefore, a rational decision-maker should be conscious that good decisionmaking requires temperate emotions that stir emotions which will then enact decisions according to the results of deliberation. Incidentally, the word 'deliberation' means literally to balance or weigh, and is derived from Latin libra, meaning 'scale'.

There are many definitions of rationality available, most of them connecting rationality with reason, but we need a definition that incorporates values and lends itself to inclusion of emotion. Føllesdal's definition of (1982) provides a useful starting point. He defines rationality in four dimensions:

1. Rationality as logical consistency. This pertains to values as well as beliefs, and is the central pieces of classical notions of rationality

2. Rationality as well-foundedness of beliefs. This means that beliefs about facts are well supported by available evidence, and that one has made a decent effort at securing relevant information.

3. Rationality as well-foundedness of values. One should have obtained reflective equilibrium that gives a stable set of convictions that are relevant for the decision situation.

4. Rationality of action. In practice, this means application of decision theory including maximization of expected utility.

While Føllesdal and others believe that, based on the principles above, one can use reason to determine which decision is rational, the findings in neuroscience suggest otherwise: conation - the desire to act - also requires emotion. One has to feel in order to act. We thus need to revise the fourth dimension:

4. Rationality of conation: Elicitation of tempered emotions that enact the beliefs and values.

The point here is that beliefs about consequences are not enough; one must also have a feeling for them. This is the only way we can ensure an ethical consequential decisionmaking.

\section{Ethics, values and emotion}

This paper has sketched a picture of a conspicuous consilience among the theories of value, ethics and neuroscience, which was first noted by Wenstøp and Myrmel (2006). We used a dialogue about control of invasive species as a background, but let us now complete the picture, first by using a general organization as an example in this chapter, and then by applying it to environmental management in chapter 10.

First, the character of people can be described in terms of virtues. There are several virtue systems such as the four cardinal virtues (prudence, justice, restraint, and courage) and the seven heavenly virtues (chastity, temperance, charity, diligence, patience, kindness, and humility). Table 1 shows the most popular corporate core values, which are models for peoples' behavior in companies. Virtuous people are met with positive emotions, but if, on the other hand, they display a lack of virtue, negative responses are usually swift and strong. Thus, there is a correspondence between virtue, and thereby virtue ethics, and affective responses through pathway e in Figure 1, which bypasses the cognitive system in people and elicits strong emotions. 


\begin{tabular}{|l|l|l|l|}
\hline Value category & Ethical theory & Emotions & Value examples \\
\hline Virtues & Virtue ethics & Strong & $\begin{array}{l}\text { integrity, honesty, respect, } \\
\text { openness, fairness, } \\
\text { innovativeness, } \\
\text { trustworthiness, creativeness, } \\
\text { reliability, dignity }\end{array}$ \\
\hline $\begin{array}{l}\text { Protected } \\
\text { values }\end{array}$ & Duty ethics & None & $\begin{array}{l}\text { Values protected by voluntary } \\
\text { standards and certificates }\end{array}$ \\
\hline Created values & Consequentialism & Tempered & $\begin{array}{l}\text { Stakeholder values such as } \\
\text { return on equity, work places, } \\
\text { products and services }\end{array}$ \\
\hline
\end{tabular}

Table 1. Correspondence of value category, ethical theory and emotion elicited in decisionmaking. Typical organizational values are shown as examples.

Second, important values are often protected by law, rights or custom; the right to land is a notable example with environmental implications. Corporations, for example, sometimes subscribe voluntarily to standards or certificates such as the UN's human rights charter against the use of child labor, and international industry standards against pollution, etc. Following such guidelines requires no emotion, but transgression is bound to elicit strong emotions.

Third, the intended consequence of organizational actions is creation of value, and in general we talk about creating value for the stakeholders. However, stakeholder values are often in conflict and decision-making requires making trade-offs among them. This again requires temperate emotions through the cognitive pathway a-b-c-d in Figure 1. See the third line in Table 1.

\section{Application to environmental management}

In their paper on value conflicts in OR, Wenstøp and Koppang (2009) propose to benchmark conflict potential according to two dimensions: The degree to which the decision criteria represent intrinsic rather than instrumental values, and the extent of stakeholder involvement. They assume that decision criteria which are only technical means to further ends are less likely to create conflicts than if they represent ends that people easily attach value to. Further, it makes a difference whether the decision is made on behalf of people such as in a board room, or whether stakeholders participate in the process, which makes the conflict potential higher.

Conflicts in environmental management notoriously engage many stakeholders who will differ over intrinsic values, and this therefore makes the conflict potential high. The raccoon dog is perhaps a minor threat, but it managed to call the attention of the Directorate for Nature Management, ornithologists, hunters, conversationalists, journalists, cabin owners, animal protectionists etc. Such conflicts call for a conceptual basis that makes it possible to understand peoples' reasons and the sources and nature of their emotions. Such a 
conceptual basis was outlined in the previous chapter, and when it is applied to environmental management, it takes the form shown in Table 2.

\begin{tabular}{|l|l|l|l|}
\hline Value category & Ethical theory & Emotions & Examples \\
\hline Virtues & Virtue ethics & Strong & $\begin{array}{l}\text { Character and intelligence of } \\
\text { animals, character of human } \\
\text { agents }\end{array}$ \\
\hline Protected values & Duty ethics & None & $\begin{array}{l}\text { Endangered species, special } \\
\text { biotopes, animal rights }\end{array}$ \\
\hline Created values & Consequentialism & Tempered & $\begin{array}{l}\text { Biodiversity, recreation, } \\
\text { beauty, } \\
\text { economic resources, food }\end{array}$ \\
\hline
\end{tabular}

Table 2. Value categories with examples of values in environmental management, the underlying ethical theory, and the level of emotions elicited in decision-making contexts.

\subsection{Virtues}

At the end of the sixteenth century, Michel de Montaigne claimed that animals are both moral and rational, but it was not until the seventeenth century that the debate gained widespread attention (Harrison, 1998). Such beliefs are still with us today as is evident when protectionists claim that animals are virtuous, or the opposite. We have seen how raccoon dogs have been vilified. Whales represent an opposite example; they have been sanctified and any discussion about whaling notoriously stir very strong emotions (Reiss, 2008). Such claims defy rationality and as such are not within the domain of OR techniques.

Thus, virtue values are outside the scope of rational approaches. That does not mean that they are irrelevant, however. All reasons are relevant but it should be recognized that the virtues of a species as a reason for decision must be treated differently from consequential reasons since they cannot be traded off on the same scale.

\subsection{Protected values}

Some values are regarded as being sufficiently important to be protected through laws, rules or regulations; and obeying them need not involve emotions - only the coldness of a bureaucratic heart, or as Weber (1947) put it: "The dominance of a spirit of formalistic impersonality, sine ira et studio, without hatred or passion, and hence without affection or enthusiasm". OR needs only to take such rules as frames or restrictions.

The problem is, however, that some values reach a protected status through emotional processes that are not necessarily rational. In the case of invasive species, xenophobia is rampant. The question of the rights of aliens, for instance, is provocative, since it is impossible to make consistent rules. The simple question, "How long must you be here to become native?" defies any logical answer. And since the real reason for pointing the finger at alien invasives is that they pose a major threat to biodiversity, the issue should become consequentialistic and not a question of rights; emotions should thus be tempered accordingly. 
The same can be said about the xenophobia that is created when alien plants or trees are considered a threat to the native landscape. According to Olwig (2003), this notion stems from a particular post-Renaissance concept of landscape, space and nature that ultimately derives from what he calls a 'cartographic-pictographic episteme'. Instead of trying to protect the existing landscape, we should acknowledge that landscapes do change and rather ask what kind of landscape do we want.

Another dubious protected value is 'genetic integrity' (Smout, 2003), which has led to campaigns against species introductions that might interbreed with natives. A more defensible approach, according to Smout, might be to revive the notion of some species as pests, but to hesitate before involving conservation in anything analogous to ethnic cleansing for other species.

\subsection{Created values}

The consequences of environmental management are called created values in Figure 1. These are the end impacts of actions, and OR embraces a set of tools that is well suited to develop consequence models to predict end impacts. System Dynamics is one example from this toolbox. But since any action is bound to have several impacts, one also needs to weigh them according to importance, for example, how much do we prefer ducks over raccoon dogs (or is it the other way around)? For that purpose we need to elicit temperate emotions among stakeholder and multi criteria methods may be useful here. See Seip and Wenstøp (2006) for an overview.

Thus, the basic recommendation of this paper is to look at the values and the reasons for them first. Put virtues aside as they must be addressed through processes outside OR. Question the protected values because they may be consequence values in disguise, and address the created values by conventional OR methods.

\subsection{Illustration: Peter Singer on whaling}

The question of whether or not to allow whaling has long been on the international forum for environmental management controversies, and few debates are more heated, with traditional whaling countries like Japan, Iceland and Norway stand on one side of the issue and environmentalists and ethicists on the other. The International Whaling Commission (IWC), with 89 member countries, is a central actor with a main duty to keep under review and revise the measures that govern the conduct of whaling throughout the world. These activities include protecting certain species, designating whale sanctuaries and setting limits on the size of catches. While the IWC's agenda is primarily scientific, based on a consequentialistic approach, any member country can reserve itself from decisions that IWC makes, and such reservations are usually made on emotional grounds.

Peter Singer is a well known ethicist and spokesman for animal rights, including whales. Let us see what he has to say in this connection (Singer, 2008): "I did not argue that whaling should stop because whales are endangered". But "whales are social mammals with big brains, capable of enjoying life and of feeling pain - and not only physical pain, but very likely also distress at the loss of one of their group." He further argues that whales cannot be humanely killed, they are too big, and using explosives would mean loss of flesh and oil, which is the very reason for hunting whales. "So harpooned whales typically die slowly and 
painfully." He concludes that "Causing suffering to innocent beings without an extremely weighty reason for doing so is wrong. If there were some life-or-death need that humans could meet only by killing whales, perhaps the ethical case against it could be countered. But there is no essential human need that requires us to kill whales. Everything we get from whales can be obtained without cruelty elsewhere. Thus, whaling is unethical."

We see that Singer starts by laying aside the consequential issue of whether whaling is sustainable. This is a scientific issue and on the agenda of the International Whaling Commission. Instead, he turns to more emotional issues, first by attributing virtue to whales, and then by arguing that whales should be protected because of their size - they cannot be killed without suffering. He does concede, however, the possibility of a consequential trade-off here, but after inspecting the ethical scales, he concludes that whales should be protected.

Thus Singer visits all three ethical categories in his chain of arguments, stirring emotions by attributing virtue to whales, as well as to convince the reader that whales should be protected to avoid suffering. Regardless of the outcome of a scientific consequential analysis of the pros and cons of whaling - such as sustainability against flesh and oil, he concludes that whaling is unethical.

Singer goes on to argue against Japan's attitude. They say "that it [Japan] wants the discussion of whaling to be carried out calmly, on the basis of scientific evidence, without "emotion." The Japanese think that humpback whale numbers have increased sufficiently for the killing of 50 to pose no danger to the species. On this narrow point, they might be right. But no amount of science can tell us whether or not to kill whales." He then dismisses Japan's call for an emotionless, scientific evaluation, seeing little added value for the Japanese regarding nutrition and health, and then accuses the Japanese of being emotional themselves, since the real reason for whaling seems to be to protect the whaling tradition.

Singer's arguments are well structured, and it is easy to identify his ethical platforms as described in this paper. They are overwhelmingly emotional, however, and therefore not susceptible to rational arguments that might be raised from a scientific OR point of view. Any decision-maker is therefore left to consider all reasons for and against whaling and use his own judgment in the matter.

\subsection{Rational consequentialistic analysis}

In management of operations, ethical decision making should start by separating created values from protected values and then proceed to work with the created ones. Protected values are highly emotional and not amenable to rational trade-off analysis, while created values can be handled through emotionally tempered processes such as multi criteria decision analysis (MCDA). See Belton and Stewart (2002) for a thorough presentation of MCDA methods. In general, the process runs like this: First one needs to represent the created values with quantitative measures, which are called decision criteria $\left(x_{1}, x_{2}, ..\right)$. Then one estimates the consequences of the decision alternatives $\left(A_{1}, A_{2}, \ldots\right)$ in terms of decision criteria scores. Uncertainty can be represented by probabilities or handled through scenario analysis. Since the consequences generally are measured on different scales, it is necessary to bring them onto the same scale, which can be done with value- or utility functions. The advantage of utility functions is that they represent attitudes towards risk; the disadvantage 
is that they are more demanding to assess. A decision problem with three alternatives and three decision criteria would be described by a table like in Table 3.

\begin{tabular}{|l|l|l|l|l|}
\hline & Option 1: $\mathrm{A}_{1}$ & Option 2: $\mathrm{A}_{2}$ & Option 3: $\mathrm{A}_{3}$ & Weight \\
\hline Criterion 1 & $x_{1}\left(\mathrm{~A}_{1}\right) \rightarrow u_{11}$ & $x_{1}\left(\mathrm{~A}_{2}\right) \rightarrow u_{12}$ & $x_{1}\left(\mathrm{~A}_{3}\right) \rightarrow u_{13}$ & $w_{1}$ \\
\hline Criterion 2 & $x_{2}\left(\mathrm{~A}_{1}\right) \rightarrow u_{21}$ & $x_{2}\left(\mathrm{~A}_{2}\right) \rightarrow u_{22}$ & $x_{2}\left(\mathrm{~A}_{3}\right) \rightarrow u_{23}$ & $w_{2}$ \\
\hline Criterion 3 & $x_{3}\left(\mathrm{~A}_{1}\right) \rightarrow u_{31}$ & $x_{3}\left(\mathrm{~A}_{2}\right) \rightarrow u_{32}$ & $x_{3}\left(\mathrm{~A}_{3}\right) \rightarrow u_{33}$ & $w_{3}$ \\
\hline Utility & $u_{1}$ & $u_{2}$ & $u_{3}$ & \\
\hline
\end{tabular}

Table 3. An MCDA decision table with three alternatives and three decision criteria.

The overall utility of an alternative is usually calculated as the weighted sum of utilities: $u_{1}=$ $w_{1} u_{11}+w_{2} u_{21}+w_{3} u_{31}$, etc. although more complicated functions that include synergy effects among the variables are available (Keeney and Raiffa, 1976) .

In cases with real value conflicts, no decision alternative will dominate the others in the sense that it scores better on all criteria, and then the optimal decision will necessarily depend on the importance of the criteria, which are represented by weights in Table 3 . While the scores are beliefs about real consequences, the weights are intrinsically subjective and will therefore depend on the values of the decision-maker. This creates two challenges. First, for a given decision-maker, one need to obtain the weights with methods that elicits temperate emotions through vivid rendering of future scenarios (Wenstøp, 2005). The field of MCDA offer several methods for achieving this (Belton and Stewart, 2002). Second, in environmental management there will usually be many stakeholders with different values, and one way to take these into account, is to try to identify viable compromises through suitable processes (Wenstøp and Koppang, 2009).

Let us now return to the issue of whaling. The two main arguments against whaling in the public debate are: (1) it is cruel (Singer, 2008), and (2) whales have rights (Johansen, 2005). Singer, as we have seen, stirs emotions in the way he argues that whales cannot possibly be killed in a humane way. Against this, the Japanese argue that, yes, by using the electric lance, whales can be killed in a humane way, at least if one compares the time it takes before the whale dies to what happens in big game hunting (Hayashi, 1996). Thus Hayashi argues that whales should not be protected by the humane killing argument, but that one should rather allow for trade-offs and treat humane killing as a created value, which then could be measured in terms of survival time in the killing process, which should be as short as possible.

The debate concerning man's rights versus animal's rights is less amenable to rational analysis. From one side the whale is portrayed as a "symbol of the mighty, uncorrupted and innocent nature as compared to the greedy, revengeful and morally depraved man". From the other side, man is portrayed as a steward on earth: "When man ate of the tree of knowledge, lost his innocence and left paradise there was no way back. Everywhere where man went to live he formed the vegetation and the landscape as a consequence of his use of nature. Man found his place in competition with and at the sacrifice of other species. He crowded out wild animals when they were competitors for food and tamed others as working force or used them as producers of food. This was, and still is, a prerequisite for 
population growth, increased productivity and cultural development. Taming of animals, use of animals, and killing of animals for food are indispensable and necessary prerequisites for man to be man; that is to build civilizations."(Johansen, 2005). - It is fair to say that this emotional debate defies consequentialistic rationality, and must be fought in a different arena.

Having thus separated created from protected values, one can proceed with those that are perceived as created (or destroyed) by whaling and which are amenable to rational analysis and trade-offs. Among these are:

- Sustenance of aborigine populations, measured as the size of populations sustained by whaling.

- Sustenance of costal populations, measured in terms of annual income from whaling.

- Health improvement from diet based on marine fatty acids, measured in terms of life years.

- Scientific information about ecosystems, especially fish/whale interactions, using the number of whales killed as an indicator.

- Commercial hunting, measured in terms of profit

- Suffering of whales killed, measured in terms of time spent in agony.

- Sustainability of whale stock, the size of the stock used as an indicator.

These created values and others can form the basis of a rational, emotionally tempered, analysis of decisions, such as setting quotas for particular whale species. This would involve estimation of consequences and subjective weighting, thus producing data that would enter a table like Table 3.

\section{Conclusion}

This paper has a modest aim: to argue that conflicts in environmental management can be better understood by sorting out the arguments according to the underling ethical platform. This provides an understanding of the degree of emotions involved and this platform serves as a tool for identifying those values that are consequential and therefore amenable to rational trade-off analysis. OR's proper arena is to provide facts regarding the consequential values and to assist in making balanced trade-offs among them. Within its proper domain, OR cannot deal with emotion-laden values such as virtues, although processes outside OR may be useful.

\section{Acknowledgment}

I want to thank Carl Brønn and Søren Wenstøp for valuable discussions and help with the manuscript.

\section{References}

2008. Handlingsplan mot mårhund, Nyctereutes procyonoides. Norway: Directorate for Nature Management.

Baron, J. \& Spranca, M. 1997. Protected values. Organizational Behavior \& Human Decision Processes, 70, 1-16. 
Belton, V. \& Stewart, T. J. 2002. Multiple Criteria Decision Analysis, Dordrecht.

Blackburn, S. 1998. Ruling Passions, A Theory of Practical Reasoning, Oxford, Clarendon.

Boulding, K. E. 1966. The ethics of rational decision. Management Science, 12, B 161-169.

Brans, J.-P. 2004. The management of the future: Ethics in OR: Respect, multicriteria management, happiness. European Journal of Operational Research, 153, 466-467.

Brans, J.-P. \& Gallo, G. 2007. Ethics in OR/MS: past, present and future. Annals of Operations Reseach, 153, 165-178.

Brans, J. P. \& Kunsch, P. L. 2010. Ethics in OR and sustainable development. International Transactions in Operational Research.

Camerer, C., Loewenstein, G. \& Prelec, D. 2005. Neuroeconomics: How neuroscience can inform economics. Journal of Economic Literature, XLIII, 9-64.

Damasio, A. R. 1994. Descartes' error. Emotion, Reason and the Human Brain, New York, G P Putnam's sons.

Davis, M. A., Chew, M. K., Hobbs, R. J., Lugo, A. E., Ewel, J. J., Vermeij, G. J., James H. Brown, Rosenzweig, M. L., Mark R. Gardener, Carroll, S. P., Ken Thompson, Pickett, S. T. A., Stromberg, J. C., Tredici, P. D., Suding, K. N., Ehrenfeld, J. G., J. Philip Grime, Mascaro, J. \& Briggs., J. C. 2011. Don't judge species on their origins. Nature, 474, 153-154.

Føllesdal, D. 1982. The Status of Rationality Assumptions in Interpretation and in the Explanation of Action. Dialectica, 36, 301-316.

Harrison, P. 1998. The Virtues of Animals in Seventeenth-Century Thought. Journal of the History of Ideas, 59, 463-484.

Hayashi, Y. 1996. Humane Killing of Whales and the Sustainable Wildlife Utilisation [Online]. Available: http://luna.pos.to/whale/icr_21_haya.html [Accessed 4. Nov. 2011].

Hough-Snee, N. 2011. Article alert: Don't judge species on their origins [Online]. Perceptible changes. Available: http:// perceptiblechanges.blogspot.com/2011/06/articlealert-dont-judge-species-on.html [Accessed August 25 2011].

Johansen, H. P. 2005. Opposition to Whaling - Arguments and Ethics. In: ENVIRONMENT, M. R. A. (ed.). Oslo: Norwegian Ministry of Fisheries and Coastal Affairs.

Keeney, R. \& Raiffa, H. 1976. Decision with Multiple Objectives, New York, John Wiley \& Sons.

Kunsch, P. L., Kavathatzopoulos, I. \& Rauschmayer, F. 2009. Modelling complex ethical decision problems with operations research. Omega, 37, 1100-1108.

Le Menestrel, M. \& Van Wassenhove, L. N. 2004. Ethics outside, within, or beyond OR models? European Journal of Operational Research, 153, 477-484.

Le Menestrel, M. \& Van Wassenhove, L. N. 2009. Ethics in Operations Research and Management Sciences: A never-ending effort to combine rigor and passion. Omega, 37, 1030-1043.

Loewenstein, G. \& Lerner, J. S. 2002. The role of affect in decision making. In: DAVIDSON, R. J. (ed.) Handbook of Affective Sciences. Cary, NC, USA: Oxford Universiry Press Inc.

Meadows, D. H., Meadows, D. \& Randers, J. 1972. The Limits of Growth. A Report for The Club of Rome's Project on the Predicament of Mankind, New York, Universe Books.

Olwig, K. R. 2003. Natives and Aliens in the National Landscape. Landscape research, 28, 6174.

Rauschmayer, F. 2001. Reflections on ethics and MCA in environmental decisions. Journal of Multi-Criteria Decision Analysis, 10, 65-74. 
Reiss, M. 2008. Ethics of whaling [Online]. Waikato: Biotechnology Learning Hub, The University of Waikato. Available:

http://www.biotechlearn.org.nz/themes/bioethics/ethics_of_whaling [Accessed September 4 2011].

Rosenhead, J. 2005. Problem structuring methods as an aid to multiple-stakeholder evaluation. In: MILLER, D. \& POTASSINI, D. (eds.) Beyond benefit cost analysis: accounting for non-market values in planning evaluation. Aldershot, UK: Ashgate Publishing Ltd.

Seip, K. L. \& Wenstøp, F. 2006. A Primer on Environmental Decision-Making: An Integrative Quantitative Approach, Springer Verlag, Dordrecht.

Singer, P. 2008. Hypocrisy on the High Seas? [Online]. Project Syndicate. Available: http://www.project-syndicate.org/commentary/singer32/English [Accessed September 5th 2011].

Smout, T. C. 2003. The Alien Species in 20th-century Britain: constructing a new vermin. Landscape research, 28, 11-20.

Sætre, S. 2010. Den fremmede (The alien). Morgenbladet, 15-20 October, p.8.

Vince, G. 2011. Embracing invasives. Science, 331 March 18, 1383-1384.

Weber, M. 1947. TheTheory of Social and Economic Organisation, New York, Free Press.

Wenstøp, F. 2005. Mindsets, rationality and emotion in Multi-criteria Decision Analysis. Journal of Multi-Criteria Decision Analysis, 13, 161-172.

Wenstøp, F. 2010. Operations research and ethics: development trends 1966-2009. International Transactions in Operational Research, 17, 413-426.

Wenstøp, F. \& Koppang, H. 2009. On operations research and value conflicts. Omega, 37, $1109-1120$.

Wenstøp, F. \& Myrmel, A. 2006. Structuring organizational value statements Management Research News, 29, 673 - 683.

Wilson, E. O. 1998. Consilience: The Unity of Knowledge, New York, Alfred A. Knopf, Inc.

Wittenberg, R. \& Cock, M. J. W. (eds.) 2001. Invasive Alien Species: A Toolkit of Best Prevention and Management Practices, Wallingford, Oxon, UK: CAB International. 


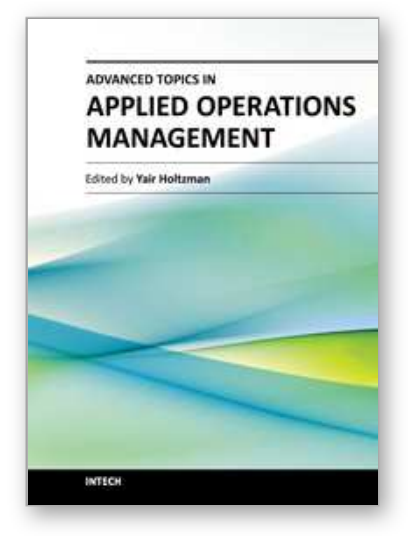

\author{
Advanced Topics in Applied Operations Management \\ Edited by Mr. Yair Holtzman
}

ISBN 978-953-51-0345-5

Hard cover, 200 pages

Publisher InTech

Published online 16, March, 2012

Published in print edition March, 2012

The chapters in Advanced Topics in Applied Operations Management creatively demonstrate a valuable connection among operations strategy, operations management, operations research, and various departments, systems, and practices throughout an organization. The authors show how mathematical tools and process improvements can be applied effectively in unique measures to other functions. The book provides examples that illustrate the challenges confronting firms competing in today's demanding environment bridging the gap between theory and practice by analyzing real situations.

\title{
How to reference
}

In order to correctly reference this scholarly work, feel free to copy and paste the following:

Fred Wenstøp (2012). A Value Structured Approach to Conflicts in Environmental Management, Advanced Topics in Applied Operations Management, Mr. Yair Holtzman (Ed.), ISBN: 978-953-51-0345-5, InTech, Available from: http://www.intechopen.com/books/advanced-topics-in-applied-operations-management/anapproach-to-value-conflicts-in-environmental-management

\section{INTECH}

open science | open minds

\section{InTech Europe}

University Campus STeP Ri

Slavka Krautzeka 83/A

51000 Rijeka, Croatia

Phone: +385 (51) 770447

Fax: +385 (51) 686166

www.intechopen.com

\section{InTech China}

Unit 405, Office Block, Hotel Equatorial Shanghai

No.65, Yan An Road (West), Shanghai, 200040, China

中国上海市延安西路 65 号上海国际贵都大饭店办公楼 405 单元

Phone: +86-21-62489820

Fax: +86-21-62489821 
(C) 2012 The Author(s). Licensee IntechOpen. This is an open access article distributed under the terms of the Creative Commons Attribution 3.0 License, which permits unrestricted use, distribution, and reproduction in any medium, provided the original work is properly cited. 